\title{
Immunomodulatory and antineoplastic efficacy of common spices and their connection with phenolic antioxidants
}

\author{
Kumar Ganesan 1, 2, Suresh Mickymaray ${ }^{3}$, Mohammed Saleh Al Aboody ${ }^{3}$, Faiz \\ Abdulaziz Alfaiz ${ }^{3}$, Rajarajan Thatchinamoorthi ${ }^{4}$, Baojun Xu ${ }^{1, *}$
}

${ }^{1}$ Food Science and Technology Program, Beijing Normal University-Hong Kong Baptist University United International College, Zhuhai 519087, China; ${ }^{2}$ Laboratory and Clinical Research Institute for Pain, Department of Anaesthesiology, The University of Hong Kong, Hong Kong, China; ${ }^{3}$ Department of Biology, College of Science, Al-Zulfi-, Majmaah University, Majmaah 11952, Riyadh region Kingdom of Saudi Arabia; ${ }^{4}$ Proteomics Lab, Bioscience Core Lab, King Abdullah University of Science and Technology, Thuwal, Kingdom of Saudi Arabia

*Corresponding author: Baojun Xu, PhD, Food Science and Technology Program, Beijing Normal University-Hong Kong Baptist University United International College, Zhuhai 519087, China

Submission Date: January10 ${ }^{\text {th }}$, 2020; Acceptance Date: February $25^{\text {th }}$, 2020, Publication Date: February $28^{\text {th }}, 2020$

Citation: Ganesan K., Mickymaray S., Aboody M.S., Alfaiz F.A., Thatchinamoorthi R., Xu B. Immunomodulatory and antineoplastic efficacy of common spices and their connection with phenolic antioxidants. Bioactive Compounds in Health and Disease 2020; 3(2): 15-31. DOI: https://doi.org/10.31989/bchd.v3i2.687

\begin{abstract}
Background: Spices have generally offered a conventional way to avert and heal various communicable and non-communicable diseases due to their efficacy and safety and their noteworthy contribution towards understanding targeted drug action and drug delivery systems. Hence, the current investigation is designed to evaluate the immunomodulatory and antineoplastic efficacy of 15 spices that connect with the flavonoid and total polyphenol ingredients. This study includes the 15 adopted spices and their total flavonoid and polyphenol contents, cell viability assay (MTT), immunomodulatory efficacy (NO, TNF- $\alpha$ ), and antineoplastic efficacy (using six cancer cell lines).
\end{abstract}

Methods: The quantification of the flavonoid and phenolic content of methanolic extracts of 15 spices was performed by colorimetric assay. The immunomodulatory efficacy was studied according to their capacity to prevent NO and TNF- $\alpha$ synthesis in LPS stimulated RAW 264.7 macrophages. Cell viability was observed using MTT colorimetric assay. Antineoplastic efficacy was determined with six cancer cell lines, namely liver (HepG2), colon (HT29), breast (MCF7), pancreas (MIA PaCa2), lung (A549) and blood (Raji). 
Results: The outcome of significant immunomodulatory efficacy of the spices was noted in the following sequences: Acorus calamus L.(Inhibition of NO-49.32 $\pm 4.29 \mu \mathrm{g} / \mathrm{mL}$ and TNF- $\alpha 96.35$ $\pm 8.23 \mu \mathrm{g} / \mathrm{mL}$ ) > Alpinia galanga Wild (Inhibition of NO-55.69 $\pm 5.89 \mu \mathrm{g} / \mathrm{mL}$ and TNF- $\alpha 102.36$ $\pm 8.96 \mu \mathrm{g} / \mathrm{mL}$ ) > Armoracia rusticana Gaerth (Inhibition of NO-82.44 $\pm 5.98 \mu \mathrm{g} / \mathrm{mL}$ and TNF- $\alpha$ $115.69 \pm 7.59$ ) > Capparis spinosa $\mathrm{L}$. (Inhibition of NO-127.59 $\pm 5.68 \mu \mathrm{g} / \mathrm{mL}$ and TNF- $\alpha 123.58$ $\pm 8.56 \mu \mathrm{g} / \mathrm{mL}$ ) $>$ Aframomum melegueta K. Schum (Inhibition of NO-169.89 $\pm 6.89 \mu \mathrm{g} / \mathrm{mL}$ and TNF- $\alpha 144.59 \pm 7.89 \mu \mathrm{g} / \mathrm{mL}$ ). The remaining spices considerably inhibited the generation of NO and TNF- $\alpha$. All spices studied exhibited highly significant antineoplastic effects against all six cell lines. Noteworthy biological activities were observed in A. calamus, A. galanga, A. rusticana, $C$. spinose, and A. melegueta which have bulk quantities of polyphenols.

Conclusion: Based on the present findings, spices are possible candidates for novel antioxidant, anti-inflammatory, and antineoplastic agents.

Keywords: Spices; cancer cell lines; immunomodulatory; antineoplastic; total polyphenol contents

\section{INTRODUCTION}

Cancer is among one of the dreaded illnesses, possesses morethan 100 diverse categories arising from various molecular alterations located in the cell. Cancer is the second foremost cause of global mortality next to cardiovascular diseases, whereby about 1 in 6 deaths are due to malignancy [1]. Between the years 2007 and 2020, the mortality rates is anticipated to increase by up to $15.2 \%$ of males and 8.1\% in females [2-4]. In 2019, the office of National Cancer Statistics stated that in the period from 2012-2016, the mortality rates in the poorest nations were double for cervical cancer and $40 \%$ higher for pulmonary and liver cancers in men [1,5]. Although mortality rates are high due to malignancy, several advances have been made with respect to the biology of the illness and treatment [3]. Over the past decade, data suggests that the cancer incidence rate can be reduced based on the opportunity for more reasonable dissemination of effective cancer prevention, early detection, and therapeutic approaches [5].

It is progressively understood that most of the recent diseases are based on the "oxidative stress" which is caused by an imbalance between the oxidizing agents (such as oxygen or hydrogen peroxide) and antioxidant compounds (such as antioxidant enzymes or antioxidant vitamins) in the body. Oxidative stress is normally generated by radicals that pursue steadiness through electron pairing with biological macromolecules (proteins, lipids, and DNA), which cause membrane damage. A free radical is a molecule that contains an unpaired electron in the related atomic orbital. The electron attaches to the structure of the mentioned biomolecules and causes cell damage due to its reactivity and instability [6]. This instability may eventually cause aging, cancer, diabetes, as well as cardiovascular and inflammatory diseases [7-10]. Almost all cells are exposed to oxidative stress, and hence, free radicals and oxidation could play a vital role in carcinogenesis at several tumor spots. Currently, free radical-stimulated oxidative stress and its significance in inflammation and malignancy are well documented [4]. Hence, there is a mutual relationship between free radicals, inflammation, and cancer. The compounds possessing free radical scavenging or antioxidant activities with anti-inflammatory potential are highly valued candidates for anticancer drugs.

This free radical-stimulated oxidative stress is however limited under normal circumstances by defensive systems of the host. These include low-molecular-weight free radical scavengers 
(thiols, quinols, ascorbic acid, tocopherols, carotenoids, polyphenols, terpenoids, urate), enzymes that eliminate either oxidants directly (superoxide dismutases) or their precursors (peroxiredoxins, glutathione peroxidases, and catalases that remove peroxides), and several enzyme systems that repair the cellular damage (methionine sulfoxide reductases, disulfide reductases/isomerases, sulfiredoxins) or eliminate impaired cellular materials (proteasomes, lysosomes, proteases, phospholipases, DNA repair enzymes) [9-13]. When an organism is exposed to a high concentration of free radical species, the endogenous antioxidant system is compromised and, thus, fails to assure the complete defense of the host. Due to the lack of these active candidates, the unavoidable expense of existing chemotherapy drugs and their complications, cancer eventually becomes aggressive and can quickly cause mortality. Thus, efforts are being made to pursue the most effective naturally occurring anti-carcinogens that would prevent, reduce, or regress tumor growth.

Spices and medicinal herbs have a distinct place in cancer therapy. Spices have been consumed as food and medicine and are used for flavoring as well as food preservatives for a long time [14]. They are readily present in the household and have been used to treat various illnesses or protect food due to their antimicrobial and powerful natural antioxidant properties [15-17]. They are well known as safe materials for food with insignificant adverse effects. The search for bioactive compounds with effective antioxidants continues to be of great significance in developing remedies against various free radical-mediated diseases. These compounds normally prevent oxidative reactions in cell mitochondria and protect against DNA damage and carcinogenesis. They are promising substances with an extensive series of pharmacological abilities such as anti-inflammatory, anti-bacterial, anti-fungal, and immunomodulatory effects [1826]. The main spice ingredients considered to have antioxidant properties are polyphenols and terpenes $[17,21]$. These secondary metabolites are potential antioxidants due to their oxidoreduction properties [20, 27-29]. Spices are used for the treatment of diseases with a systematic modality constructed based on their antioxidant properties. The random use of herbal medicine is technically not lawful due to the absence of noxious pharmacological host testing. However, the conventional spices do not cause any host toxicity and could be candidates in discovering and developing new anti-inflammatory and antineoplastic agents. Taking this into consideration, the current study aimed to evaluate the immunomodulatory and antineoplastic efficacy of 15 common spices that connect with the antioxidant properties of total phenol and flavonoid contents.

\section{MATERIALS AND METHODS}

Chemicals and culture

Lipopolysaccharide (LPS, Cat No. L2887), mouse macrophages (RAW 264.7, Cat. No. 91062702), dimethyl sulfoxide (DMSO, Cat. No. 101900), trypan blue (Cat. No. T6146), 3-(4,5dimethylthiazol-2-yl)-2, 5-diphenyltetrazolium bromide (MTT, Cat. No. M5655), sulphanilamide (Cat.No.33626), tetra-methyl benzidine, (Cat. No. T5513) and N-(1-1-napthyl) ethylenediamine dihydrochloride (Cat. No. N9125), Dulbecco's modified eagle's medium (DMEM, Cat. No. D6046), fetal bovine serum (FBS, Cat. No. F2442), and antibiotics (Penicillin and streptomycin, cat. No. 516106) were acquired from Sigma Aldrich, MO, USA. ELISA standard kit, TNF- $\alpha$ (Cat. No. 560479), and NO (Cat. No. 23479) were procured from BD Biosciences, San Jose, CA, USA. Six cancer cell lines, namely liver (HepG2), colon (HT29), breast (MCF7), pancreas (MIA PaCa2), lung (A549) and blood (Raji) were obtained from the American Type Culture Collection (ATCC), Manassas, VA, USA. 


\section{Preparation of spice extracts}

The spices were identified and confirmed with reference to Herbarium sheets available in The Rapinat Herbarium and the Centre for Molecular Systematics, St. Joseph's College, Tiruchirappalli, Tamil Nadu, India. Ten grams of a spice powder were solubilized using 100-mL of methanol and kept at $4^{\circ} \mathrm{C}$ for 72 hours. The composite was then filtered and the filtrate was concentrated to a sticky mass in a rotary evaporator at room temperature; the quantity was calculated and solubilized in $1 \mathrm{~mL} 10 \% \mathrm{v} / \mathrm{v}$ DMSO; all the spice extracts were kept at $4{ }^{\circ} \mathrm{C}$ for further use [16].

\section{Quantification of total phenolic content}

The quantity of total phenol was assayed by the Folin-Ciocalteu method using spectrophotometry with minor changes [30]. $2 \mathrm{~mL}$ of Folin-Ciocalteu was added with $0.2 \mathrm{~mL}$ methanolic spice extract and $5 \mathrm{~mL}$ of $20 \% \mathrm{w} / \mathrm{v}$ sodium carbonate. The composite was placed in a dark location at $37^{\circ} \mathrm{C}$ for at least $30 \mathrm{~min}$ and the measurement was read using a spectrophotometer (Thermo Fisher Scientific, Waltham, MA, USA) at $765 \mathrm{~nm}$. Total phenolics were calibrated by gallic acid as a standard. All analyses were replicated. Total phenolics are expressed as $\mathrm{mg}$ of gallic acid equiv/g of dry mass.

\section{Quantification of total flavonoid content}

Total flavonoids were quantified by the method of Stojanović et al. [31] using aluminium chloride $\left(\mathrm{AlCl}_{3}\right)$. Thereby, $0.5 \mathrm{~mL}$ of the spice extract was mixed with $0.5 \mathrm{~mL}$ of the reaction medium methanol: water: acetic acid in the ratio of 14:5:1. This prepared solution was added to $4 \mathrm{~mL}$ of the $\mathrm{AlCl}_{3}$ reagent and kept at $37^{\circ} \mathrm{C}$ for $5 \mathrm{~min}$. The absorbance was read using a spectrophotometer at $430 \mathrm{~nm}$. Total flavonoid content was expressed by $\mathrm{mg}$ rutin equiv/g dry mass.

\section{Assays for immunomodulatory activity}

\section{Activation of RAW 264.7 macrophages}

This assay was carried out based on the methods of Ni et al. [32], Zhang et al. [33], and Zhang et al. [34] with slight modifications. RAW 264.7 cells were added to a DMEM medium (containing $1 \%$ antibiotic with $5 \%$ w/v FBS) and incubated for at least $4-7$ days at $37^{\circ} \mathrm{C}$ in $5 \% \mathrm{CO}_{2}$ to obtain the cell density of $2 \times 10^{5}$ cells $/ \mathrm{mL}$.

\section{$N O$, and TNF- $\alpha$ production}

About $100 \mu \mathrm{L}$ of the supernatant was carefully transferred from the respective well to 6 well plates. $50 \mu \mathrm{L}$ of sulfanilamide $(1 \% \mathrm{w} / \mathrm{v})$ containing $\mathrm{H}_{3} \mathrm{PO}_{4}(5 \% \mathrm{w} / \mathrm{v})$ was added to the supernatant and stored for 5 minutes at $37^{\circ} \mathrm{C}$. followed by adding $50 \mu \mathrm{L}$ of Naphthyl ethylenediamine $(0.1 \% \mathrm{w} / \mathrm{v})$ to analyze the generation of NO based on the methods of Ni et al. [32], Zhang et al. [33], and Zhang et al. [34]. Sodium nitrate was used as a standard. The ELISA kit was used to analyze (800 ${ }^{\mathrm{TM}}$ TS ELISA Absorbance Reader, Bio Tek Instruments, Winooski, VT, USA) the TNF- $\alpha$ concentration as per the procedure of Zhang et al. [35] All analyses were conducted three times. 
RAW 264.7 cells are macrophage-like cells that are suitable models of macrophages. The viability of RAW 264.7 cells was determined by performing the MTT colorimetric assay, which is in accordance with the mitochondrial activity. [36] Thereby, RAW 264.7 cells were preserved with spice extracts that were stored at $37^{\circ} \mathrm{C}$ for $24 \mathrm{~h}$. The supernatant was then discarded and $100 \mu \mathrm{L}$ of MTT $(0.2 \mathrm{mg} / \mathrm{mL}$, dissolved in DMEM) was added to each well and stored for additional incubation for $4 \mathrm{~h}$. The supernatant was removed and $50 \mu \mathrm{L}$ of DMSO was added to each well to soften the crystal-like formation. The mentioned activity in the living cells is stable and increasing or decreasing the number of living cells is therefore linearly associated with the mitochondrial activity. Tetrazolium MTT staining is activated in the metabolically active cells. Finally, the absorbance was read using colorimetry (Thermo Fisher Scientific, Waltham, MA, USA) at 595 $\mathrm{nm}$. The cell viabilities were measured by the following equation:

$$
\text { Inhibition }(\%)=\frac{O D \text { sample-OD positive control }}{O D \text { negative control-OD positive control }} \times 100
$$

\section{Antineoplastic assays using six cancer cell lines}

All six cancer cell lines were cultivated and protected on the basis of the previous methods with slight modifications [36]. The antineoplastic efficacy was determined using various cancer cell lines, namely liver (HepG2), colon (HT29), breast (MCF7), pancreas (MIA PaCa2), lung (A549) and blood (Raji). The optical density was read using a spectrofluorometer (Jasco FP-8300 Spectrofluorometer, Easton, MD, USA) at $570 \mathrm{~nm}$. DMSO was used as a negative control. The inhibition of different cancer cells $(\%)$ was analyzed using the following equation:

\section{Statistical Analysis}

$$
\text { Cell viability }(\%)=\frac{O D \text { sample }}{\text { OD positive control }} \times 100
$$

The data are given as means \pm SD. The result outcomes were matched by a one-way analysis of variance (ANOVA) using SPSS version 22.0 (SAS Institute Inc., Cary, NC, USA). Duncan's multiple range test was employed to find significant changes among the means. The differences at the $5 \%$ level $(p<0.05)$ were measured statistically significant.

\section{RESULTS}

Ethnomedicinal uses of 15 common spices and their immunomodulatory and antineoplastic efficacy are shown in Table 1 . These spices are widely consumed worldwide for culinary and infectious ailments. The results of total flavonoid and polyphenol content of 15 spices are presented in Table 2, which was quantified using aluminium chloride and Folin-Ciocalteu methods, respectively. Flavonoid and polyphenol contents were expressed as $\mathrm{mg}$ of rutinequiv/gm of dry mass and mg of gallic acid-equiv/gm of spice dry mass respectively. The greater contents of total flavonoid and polyphenol content of the five spices were listed based on the order: Acorus calamus $>$ Alpinia galanga $>$ Armoracia rusticana $>$ Capparis spinosa $>$ A. melegueta. The highest flavonoid and phenolic contents were observed in the extracts of Acorus calamus $L$. $(133.48 \pm 10.2 \mathrm{mg} / \mathrm{g}$ and $190.5 \pm 15.6 \mathrm{mg} / \mathrm{g})$. Usually, the amplified generation of TNF- $\alpha$ and NO produces inflammation. The present study examined the abilities of the 15 spice extracts to inhibit the production of NO and TNF- $\alpha$ in LPS-induced RAW 264.7 cells. The inhibitory activity was measured as $\mathrm{CC}_{50}$ values and the results are shown in Table 3. 
Table 1 Selected common spices for assay of immunomodulatory and antineoplastic effect [14$17,26]$

\begin{tabular}{|c|c|c|c|c|c|}
\hline S.No & Spices & Family & $\begin{array}{l}\text { Common } \\
\text { name }\end{array}$ & $\begin{array}{l}\text { Portions } \\
\text { used }\end{array}$ & Ethnomedicinal practices \\
\hline 1 & Acorus calamus $\mathrm{L}$. & Araceae & Sweet flag & Rhizome & $\begin{array}{l}\text { Used to cure inflammation of the } \\
\text { stomach lining (gastritis) }\end{array}$ \\
\hline 2 & $\begin{array}{l}\text { Aframomum } \\
\text { melegueta } \mathrm{K} . \\
\text { Schum. }\end{array}$ & Zingiberaceae & $\begin{array}{l}\text { Grains of } \\
\text { Paradise }\end{array}$ & Seed & $\begin{array}{l}\text { Used as a purgative, galactagogue, } \\
\text { anthelmintic, and potent anti- } \\
\text { inflammatory activity }\end{array}$ \\
\hline 3 & $\begin{array}{l}\text { Alpinia galanga } \\
\text { Wild }\end{array}$ & Zingiberaceae & Galanga & Rhizome & $\begin{array}{l}\text { Used to treat indigestion, colic and } \\
\text { dysentery, cancers of mouth and } \\
\text { stomach and systemic infections }\end{array}$ \\
\hline 4 & $\begin{array}{l}\text { Anethum } \\
\text { graveolens L. }\end{array}$ & Apiaceae & Dill seed & Fruits & $\begin{array}{l}\text { Used as carminative, stomachic } \\
\text { and diuretic and relieve colic pain }\end{array}$ \\
\hline 5 & $\begin{array}{l}\text { Apium graveolens } \\
\text { L. }\end{array}$ & Apiaceae & Celery & Seed & $\begin{array}{l}\text { Used as diuretic, laxative, and } \\
\text { sedative and blood cancer }\end{array}$ \\
\hline 6 & $\begin{array}{l}\text { Armoracia } \\
\text { rusticana Gaerth }\end{array}$ & Brassicaceae & $\begin{array}{l}\text { Horse } \\
\text { Radish }\end{array}$ & Root & $\begin{array}{l}\text { Used as antiseptic, and value in the } \\
\text { treatment of colds, fevers and } \\
\text { respiratory and urinary tract } \\
\text { infections }\end{array}$ \\
\hline 7 & $\begin{array}{l}\text { Artemisia } \\
\text { dracunculus } \mathrm{L} .\end{array}$ & Asteraceae & Tarragon & Leaf & $\begin{array}{l}\text { Stimulates the digestive system and } \\
\text { uterus, lowers fevers and destroys } \\
\text { intestinal worms }\end{array}$ \\
\hline 8 & Capparis spinosa L. & Capparidaceae & Caper & $\begin{array}{l}\text { Flower } \\
\text { buds }\end{array}$ & Used to treat hemorrhoids and gout \\
\hline 9 & Carum carvi $L$. & Apiaceae & Caraway & Fruits & $\begin{array}{l}\text { Used to dyspepsia, and various } \\
\text { spasmodic conditions, bloating, } \\
\text { and diarrhoea }\end{array}$ \\
\hline 10 & Citrus hystrix DC & Rutaceae & $\begin{array}{l}\text { Kaffir Lime } \\
\text { Leaves }\end{array}$ & Leaves & $\begin{array}{l}\text { Used against stomach pain, } \\
\text { diarrhea, and indigestion }\end{array}$ \\
\hline 11 & Crocus sativus $L$. & Iridaceae & Saffron & $\begin{array}{l}\text { Parts of } \\
\text { pistil }\end{array}$ & $\begin{array}{l}\text { Useful for asthma, whooping } \\
\text { cough and to release phlegm, } \\
\text { sleep problems and cancer }\end{array}$ \\
\hline 12 & $\begin{array}{l}\text { Elettaria } \\
\text { cardamomum (L.) } \\
\text { Maton }\end{array}$ & Zingiberaceae & Cardamom & Fruits & $\begin{array}{l}\text { Used to cure dysentery, swelling, } \\
\text { bronchitis, and cough }\end{array}$ \\
\hline 13 & Ferula asafetida $L$. & Apiaceae & Asafoetida & $\begin{array}{l}\text { Resin } \\
\text { From } \\
\text { rhizome }\end{array}$ & $\begin{array}{l}\text { Used against indigestion, swelling, } \\
\text { and toothache }\end{array}$ \\
\hline 14 & $\begin{array}{l}\text { Garcinia indica } \\
\text { Choisy }\end{array}$ & Clusiaceae & Kokam & Rind & $\begin{array}{l}\text { Used in the treatment of } \\
\text { inflammatory ailments for } \\
\text { rheumatic pains and bowel } \\
\text { complaints }\end{array}$ \\
\hline 15 & $\begin{array}{l}\text { Hyssopus } \\
\text { officinalis } \mathrm{L} .\end{array}$ & Lamiaceae & Hyssop & Leaf & $\begin{array}{l}\text { Useful for sore throats, colds, } \\
\text { hoarseness, and as an expectorant }\end{array}$ \\
\hline
\end{tabular}


Table 2. Flavonoid and polyphenolic content of methanolic extracts of 15 spices.

\begin{tabular}{|c|c|c|c|}
\hline S.No & Spices & $\begin{array}{l}\text { Flavonoids } \\
\text { (mg RE/g DE) }\end{array}$ & $\begin{array}{l}\text { Polyphenols } \\
\text { (mg GAE/g DE) }\end{array}$ \\
\hline 1. & Acorus calamus $\mathrm{L}$. & $133.48 \pm 10.2^{\mathrm{a}}$ & $190.5 \pm 15.6^{\mathrm{a}}$ \\
\hline 2. & Aframomum melegueta K. Schum. & $95.39 \pm 8.92^{\mathrm{b}, \mathrm{c}}$ & $138.36 \pm 9.5^{\mathrm{d}}$ \\
\hline 3. & Alpinia galanga Wild & $125.89 \pm 12.3^{\mathrm{a}}$ & $173.45 \pm 10.9^{\mathrm{b}}$ \\
\hline 4. & Anethum graveolens $L$. & $92.54 \pm 7.49^{b, c}$ & $99.25 \pm 8.9^{\mathrm{e}}$ \\
\hline 5. & Apium graveolens $L$. & $78.67 \pm 6.95^{\mathrm{d}}$ & $85.95 \pm 6.4^{\mathrm{e}}$ \\
\hline 6. & Armoracia rusticana Gaerth & $112.24 \pm 11.4^{\mathrm{b}}$ & $158.15 \pm 12.3^{\mathrm{c}}$ \\
\hline 7. & Artemisia dracunculus L. & $89.35 \pm 6.8^{\mathrm{b}}$ & $99.95 \pm 9.8^{\mathrm{e}}$ \\
\hline 8. & Capparis spinosa L. & $101.28 \pm 9.65^{\mathrm{b}, \mathrm{c}}$ & $144.26 \pm 11.2^{\mathrm{d}}$ \\
\hline 9. & Carum carvi $L$. & $60.59 \pm 5.64^{\mathrm{e}}$ & $72.58 \pm 5.69^{\mathrm{e}}$ \\
\hline 10. & Citrus hystrix DC & $75.48 \pm 6.25^{\mathrm{d}}$ & $86.49 \pm 5.98^{\mathrm{e}}$ \\
\hline 11. & Crocus sativus $L$. & $59.68 \pm 6.58^{\mathrm{e}}$ & $72.89 \pm 5.21^{\mathrm{e}}$ \\
\hline 12. & Elettaria cardamomum (L.) Maton & $55.49 \pm 5.98^{\mathrm{e}}$ & $59.56 \pm 4.56^{\mathrm{f}}$ \\
\hline 13. & Ferula asafetida $L$. & $85.38 \pm 6.27^{\mathrm{c}}$ & $89.44 \pm 6.48^{\mathrm{e}}$ \\
\hline 14. & Garcinia indica Choisy & $76.49 \pm 5.87^{\mathrm{d}}$ & $88.35 \pm 4.59^{\mathrm{e}}$ \\
\hline 15. & Hyssopus officinalis L. & $38.66 \pm 4.23^{f}$ & $45.08 \pm 3.56^{\mathrm{f}}$ \\
\hline
\end{tabular}

Results are Means \pm SD. Values not sharing a common superscript (a-f) differ significantly at $p<0.05$, Duncan's Multiple Range Test (DMRT). The quantity of flavonoid is expressed as mg of rutin-equiv/ gm of dry mass and the quantity of polyphenol is expressed as $\mathrm{mg}$ of gallic acid-equiv/gm of dry mass. All analyses were conducted triplicate.

Table 3: Immunomodulatory effect of the various spices

\begin{tabular}{|c|c|c|c|c|}
\hline Name of the spices & $\begin{array}{l}\mathrm{CC}_{50} \text { for the } \\
\text { inhibition of } \mathrm{NO} \\
\text { production }(\mu \mathrm{g} / \mathrm{mL})^{*}\end{array}$ & $\begin{array}{l}\text { Cell viability (\% } \\
\text { of cell survival)** }\end{array}$ & $\begin{array}{l}\mathrm{CC}_{50} \text { for the inhibition of } \\
\mathrm{TNF}-\alpha \text { production } \\
(\mu \mathrm{g} / \mathrm{mL})^{*}\end{array}$ & $\begin{array}{l}\text { Cell viability (\% } \\
\text { of cell } \\
\text { survival)** }\end{array}$ \\
\hline Acorus calamus L. & $49.32 \pm 4.29$ & $108.95 \pm 4.26$ & $96.35 \pm 8.23$ & $95.26 \pm 7.45$ \\
\hline $\begin{array}{l}\text { Aframomum melegueta } \\
\text { K. Schum. }\end{array}$ & $169.89 \pm 6.89$ & $86.98 \pm 9.15$ & $144.59 \pm 7.89$ & $78.95 \pm 8.15$ \\
\hline Alpinia galanga Wild & $55.69 \pm 5.89$ & $102.38 \pm 4.59$ & $102.36 \pm 8.96$ & $93.58 \pm 6.32$ \\
\hline Anethum graveolens $L$. & $226.84 \pm 9.54$ & $83.58 \pm 9.25$ & $178.95 \pm 7.59$ & $70.25 \pm 6.58$ \\
\hline Apium graveolens $L$. & $357.48 \pm 11.28$ & $80.26 \pm 6.25$ & $324.59 \pm 7.84$ & $58.56 \pm 5.49$ \\
\hline $\begin{array}{l}\text { Armoracia rusticana } \\
\text { Gaerth }\end{array}$ & $82.44 \pm 5.98$ & $98.74 \pm 6.59$ & $115.69 \pm 7.59$ & $89.89 \pm 7.85$ \\
\hline $\begin{array}{l}\text { Artemisia dracunculus } \\
\text { L. }\end{array}$ & $589.64 \pm 15.67$ & $52.35 \pm 6.38$ & $554.25 \pm 14.56$ & $38.97 \pm 5.68$ \\
\hline Capparis spinosa L. & $127.59 \pm 5.68$ & $91.35 \pm 8.95$ & $123.58 \pm 8.56$ & $83.28 \pm 8.45$ \\
\hline Carum carvi $L$ & $238.94 \pm 9.89$ & $81.36 \pm 8.58$ & $298.94 \pm 12.35$ & $60.23 \pm 5.68$ \\
\hline Citrus hystrix DC & $338.79 \pm 9.56$ & $76.56 \pm 9.15$ & $314.67 \pm 12.39$ & $59.68 \pm 6.32$ \\
\hline Crocus sativus $L$. & $229.89 \pm 7.14$ & $83.14 \pm 8.14$ & $289.25 \pm 14.5$ & $64.56 \pm 5.79$ \\
\hline $\begin{array}{l}\text { Elettaria cardamomиm } \\
\text { (L.) Maton }\end{array}$ & $697.45 \pm 12.7$ & $48.68 \pm 4.56$ & $559.24 \pm 12.5$ & $37.49 \pm 4.56$ \\
\hline Ferula asafetida $L$. & $456.9 \pm 13.47$ & $68.57 \pm 7.25$ & $439.78 \pm 9.25$ & $41.85 \pm 4.67$ \\
\hline Garcinia indica Choisy & $545.69 \pm 18.5$ & $55.69 \pm 8.25$ & $512.58 \pm 9.57$ & $40.25 \pm 5.59$ \\
\hline Hyssopus officinalis L. & $467.89 \pm 9.87$ & $69.25 \pm 7.59$ & $416.89 \pm 8.45$ & $44.56 \pm 6.59$ \\
\hline
\end{tabular}

*Inhibition of NO and TNF- $\alpha$ generation was expressed in terms of $\mathrm{CC}_{50}, \mathrm{p}<0.05$; **cell viability was measured at quantity $1 \mathrm{mg} / \mathrm{mL}$ of the spice extract. 
Cell viability was measured at $1 \mathrm{mg} / \mathrm{mL}$ of the spice extract. It was realized that all spice extracts showed cell viability and noteworthy inhibitory activity against the generation of $\mathrm{NO}$ and TNF- $\alpha$. However, five spices exhibited stronger cell viability and inhibitory activity in the sequence of $A$. calamus $>A$. galanga $>A$. rusticana $>C$. spinosa $>A$. melegueta against the production of NO and TNF- $\alpha$ with $\mathrm{CC}_{50}$ values when compared with other spices. A. calamus $\mathrm{L}$ and $A$. galanga wild showed a significantly higher cell viability rate $(108.95 \%$ and $102.38 \%)$ against NO production. Additionally, A. calamus L. wild exhibited significantly higher cell viabilities $(95.26 \%)$ against TNF- $\alpha$ production. This plant displayed higher inhibitory activity against the generation of NO and TNF- $\alpha$ with $\mathrm{CC}_{50}$ values that are less than $49.32 \pm 4.29 \mu \mathrm{g} / \mathrm{mL}$ and $96.35 \pm 8.23 \mu \mathrm{g} / \mathrm{mL}$ respectively. The concentration-dependent (15.625 to $1000 \mu \mathrm{g} / \mathrm{mL}$ ) immunomodulatory activities of most effective extracts from the listed spices are shown in Figures $1 \mathrm{a}$ and $1 \mathrm{~b}$.

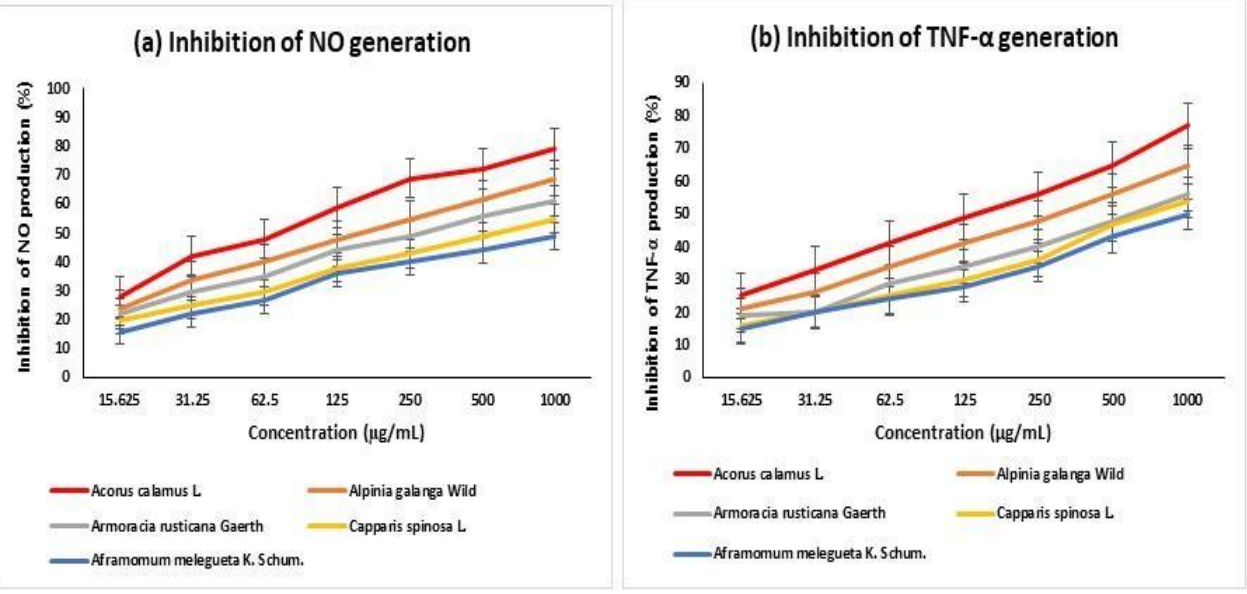

(e) Anticancer activity
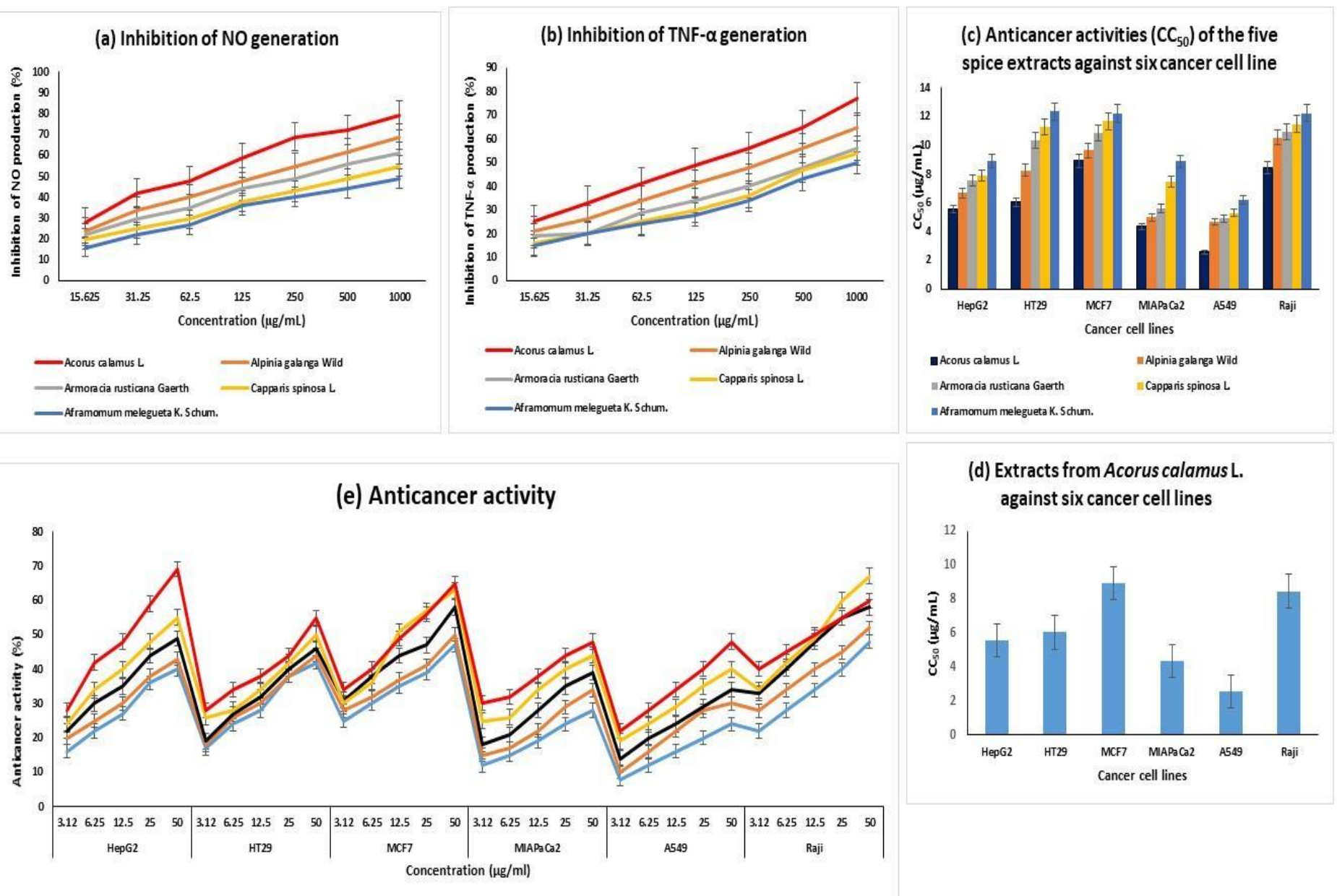

(d) Extracts from Acorus calamus L. against six cancer cell lines

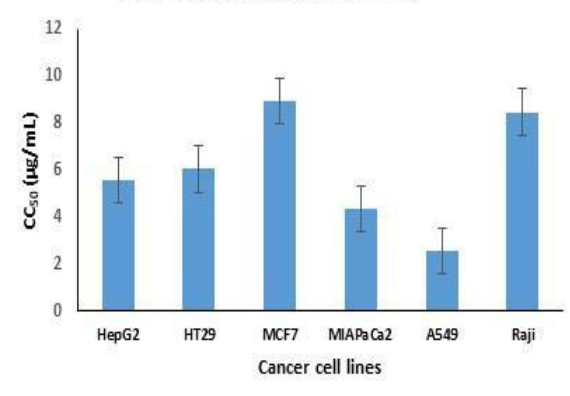

- Acorus calamus L. - Alpinia galanga Wild —Armoracia rusticana Gaerth —Capparis spinosa L —Aframomum melegueta K.Schum.

Figure 1: (a) Concentration-dependent immunomodulatory effect (NO generation) of most effective spices from the list; (b) Concentration-dependent immunomodulatory effect (TNF- $\alpha$ generation) of most effective spices from the list (c) Antineoplastic potential $\left(\mathrm{CC}_{50}\right)$ of the 5 spice extracts against six various cell line (d) Methanolic extracts from Acorus calamus L. against six cancer cell lines. (e) Dose-dependent variation of antineoplastic activities of the selected five most active spices. Results are mean \pm SD. All analyses were conducted triplicate, $p<0.05$. 
Table 4: Cytotoxicity effect of 15 spices against six cancer cell lines

\begin{tabular}{|c|c|c|c|c|c|c|}
\hline \multirow[t]{2}{*}{ Name of the spices } & \multicolumn{6}{|c|}{$\mathrm{CC}_{50}(\mu \mathrm{g} / \mathrm{mL})^{*}$} \\
\hline & HepG2 & HT29 & MCF7 & MIA PaCa2 & A549 & Raji \\
\hline Acorus calamus $\mathrm{L}$. & $5.56 \pm 1.03$ & $6.05 \pm 1.89$ & $8.92 \pm 1.31$ & $4.35 \pm 0.65$ & $2.58 \pm 0.65$ & $8.45 \pm 4.56$ \\
\hline $\begin{array}{l}\text { Aframomum melegueta } \\
\text { K. Schum. }\end{array}$ & $8.89 \pm 1.25$ & $\begin{array}{l}12.35 \pm \\
1.58\end{array}$ & $\begin{array}{l}12.22 \pm \\
2.35\end{array}$ & $8.88 \pm 1.58$ & $6.22 \pm 0.58$ & $12.25 \pm 2.58$ \\
\hline Alpinia galanga Wild & $6.68 \pm 0.89$ & $8.26 \pm 1.89$ & $9.63 \pm 2.45$ & $4.99 \pm 0.96$ & $4.65 \pm 0.78$ & $10.56 \pm 1.36$ \\
\hline Anethum graveolens $L$. & $\begin{array}{l}10.68 \pm \\
0.25\end{array}$ & $\begin{array}{l}14.65 \pm \\
0.89\end{array}$ & $\begin{array}{l}14.56 \pm \\
2.91\end{array}$ & $9.25 \pm 1.51$ & $\begin{array}{l}10.24 \pm \\
1.35\end{array}$ & $14.28 \pm 2.35$ \\
\hline Apium graveolens $L$. & $9.98 \pm 0.45$ & $\begin{array}{l}14.44 \pm \\
0.95\end{array}$ & $\begin{array}{l}15.22 \pm \\
1.58\end{array}$ & $9.52 \pm 1.93$ & $9.58 \pm 1.87$ & $19.48 \pm 1.53$ \\
\hline $\begin{array}{l}\text { Armoracia rusticana } \\
\text { Gaerth }\end{array}$ & $7.58 \pm 5.68$ & $\begin{array}{l}10.35 \pm \\
5.68\end{array}$ & $\begin{array}{l}10.89 \pm \\
3.25\end{array}$ & $5.59 \pm 1.35$ & $4.89 \pm 2.58$ & $10.95 \pm 2.01$ \\
\hline $\begin{array}{l}\text { Artemisia dracunculus } \\
\text { L. }\end{array}$ & $\begin{array}{l}17.23 \pm \\
1.34 \\
\end{array}$ & $\begin{array}{l}18.59 \pm \\
0.25\end{array}$ & $\begin{array}{l}19.89 \pm \\
0.89\end{array}$ & $18.77 \pm 2.55$ & $\begin{array}{l}19.12 \pm \\
1.73\end{array}$ & $15.59 \pm 1.25$ \\
\hline Capparis spinosa $\mathrm{L}$. & $7.89 \pm 3.25$ & $\begin{array}{l}11.28 \pm \\
4.78\end{array}$ & $\begin{array}{l}11.68 \pm \\
3.68\end{array}$ & $7.48 \pm 1.25$ & $5.28 \pm 2.59$ & $11.48 \pm 1.28$ \\
\hline Carum carvi $L$. & $\begin{array}{l}14.65 \pm \\
0.95\end{array}$ & $\begin{array}{l}19.52 \pm \\
2.35\end{array}$ & $\begin{array}{l}18.98 \pm \\
2.55\end{array}$ & $18.99 \pm 2.35$ & $\begin{array}{l}15.26 \pm \\
0.56\end{array}$ & $16.32 \pm 1.25$ \\
\hline Citrus hystrix DC & $\begin{array}{l}10.98 \pm \\
1.25\end{array}$ & $\begin{array}{l}17.89 \pm \\
1.89\end{array}$ & $\begin{array}{l}19.89 \pm \\
2.65\end{array}$ & $18.23 \pm 1.65$ & $\begin{array}{l}18.98 \pm \\
1.25\end{array}$ & $19.86 \pm 2.22$ \\
\hline Crocus sativus $L$. & $\begin{array}{l}16.65 \pm \\
0.59\end{array}$ & $\begin{array}{l}18.44 \pm \\
1.63\end{array}$ & $\begin{array}{l}19.23 \pm \\
1.62\end{array}$ & $18.13 \pm 1.47$ & $\begin{array}{l}13.25 \pm \\
0.25\end{array}$ & $15.89 \pm 1.05$ \\
\hline $\begin{array}{l}\text { Elettaria cardamomиm } \\
\text { (L.) Maton }\end{array}$ & $\begin{array}{l}13.68 \pm \\
2.22\end{array}$ & $\begin{array}{l}18.98 \pm \\
4.56\end{array}$ & $\begin{array}{l}14.56 \pm \\
5.47\end{array}$ & $12.56 \pm 2.65$ & $\begin{array}{l}18.25 \pm \\
2.56\end{array}$ & $15.69 \pm 3.32$ \\
\hline Ferula asafetida $L$ & $\begin{array}{l}16.58 \pm \\
5.68\end{array}$ & $\begin{array}{l}22.35 \pm \\
5.68\end{array}$ & $\begin{array}{l}16.89 \pm \\
3.25\end{array}$ & $10.59 \pm 1.35$ & $\begin{array}{l}14.89 \pm \\
2.58\end{array}$ & $12.35 \pm 2.01$ \\
\hline Garcinia indica Choisy & $\begin{array}{l}10.25 \pm \\
1.35\end{array}$ & $\begin{array}{l}18.87 \pm \\
2.25\end{array}$ & $\begin{array}{l}12.56 \pm \\
1.29\end{array}$ & $10.67 \pm 2.91$ & $\begin{array}{l}10.12 \pm \\
1.54\end{array}$ & $13.65 \pm 0.98$ \\
\hline Hyssopus officinalis L. & $\begin{array}{l}15.56 \pm \\
2.03\end{array}$ & $\begin{array}{l}16.05 \pm \\
5.89\end{array}$ & $\begin{array}{l}18.92 \pm \\
2.31\end{array}$ & $14.35 \pm 2.65$ & $\begin{array}{l}12.58 \pm \\
3.65\end{array}$ & $18.45 \pm 4.56$ \\
\hline
\end{tabular}

* Smaller $\mathrm{CC}_{50}$ value indicates higher cytotoxicity activity, Mean $\pm \mathrm{SD}$

All spice extracts had noteworthy higher immunomodulatory activity. Among them, A. calamus $L$. had maximum inhibitory activities against NO as well as TNF- $\alpha$ production. The upright relationship between the immunomodulatory effects of the spices and their flavonoid and polyphenol contents shown in Table 5 were fascinating results.

Notably, A. calamus, A. galanga, A. rusticana, C. spinosa, and A. melegueta had remarkable inhibition in the generation of $\mathrm{NO}$ as well as TNF- $\alpha$ (in terms of lower $\mathrm{CC}_{50}$ values) and also had maximum quantities of flavonoid and total phenol. Other spices were identified to contain low quantities of flavonoid and total phenol that showed less immunomodulatory effects (Tables 2 and $3)$. The antineoplastic efficacy of the extracts from 15 spices was evaluated in six cancer cell lines including liver (HepG2), colon (HT29), breast (MCF7), pancreas (MIA PaCa2), lung (A549) and blood (Raji). These results are shown in Table 4. It is interesting that all listed spices had a potential cytotoxic effect that significantly inhibited growth in all six cancer cell lines. The correlation of antineoplastic efficacy of spices and their flavonoid and polyphenol quantities are presented in Table 4. Notably, five spices demonstrated stronger cytotoxicity activity in the sequence of $A$. calamus $>$ A. galanga $>$ A. rusticana $>C$. spinosa $>$ A. melegueta against six cancer cell lines with lower $\mathrm{CC}_{50}$ values when compared with other spices (Figure 1c). Normally, the smaller $\mathrm{CC}_{50}$ value 
showed higher cytotoxicity activity. During this investigation, A.calamus L. had maximum antineoplastic activities against the following sequence of cancer lines: lung> pancreas $>$ liver $>$ colon $>$ blood $>$ breast $\quad$ (Figure 1d). Dose-dependent $(3.12$ to $50 \mu \mathrm{g} / \mathrm{mL}$ ) antineoplastic activities of the most effective extracts from the listed spices are shown in Figure 1 e.

All spice extracts had noteworthy higher antineoplastic activities against all six cancer cell lines. Spices examined in this study demonstrated a substantial correlation of antineoplastic activities with their flavonoid and phenolic contents. Notably, A. calamus, A. galanga, A. rusticana, $C$. spinosa, and $A$. melegueta contained maximum to medium quantities of flavonoid and polyphenols that exhibited significant antineoplastic activities (Table 5).

Table 5: Antineoplastic spices identified in the investigations together with the total flavonoid and polyphenol contents.

\begin{tabular}{|c|c|c|c|c|c|}
\hline Spices & $\begin{array}{l}\text { Total flavonoid } \\
\text { contents }\end{array}$ & $\begin{array}{l}\text { Total } \\
\text { polyphenol } \\
\text { contents }\end{array}$ & $\begin{array}{l}\text { Immunomod } \\
\text { ulatory } \\
\text { activity }\end{array}$ & $\begin{array}{l}\text { Antineoplasti } \\
\text { c activity }\end{array}$ & Comments \\
\hline Acorus calamus L. & $133.48 \pm 10.2^{\mathrm{a}}$ & $190.5 \pm 15.6^{\mathrm{a}}$ & ++ & ++ & $\begin{array}{l}\text { Highly potential } \\
\text { candidate }\end{array}$ \\
\hline $\begin{array}{l}\text { Aframomum melegueta } \\
\text { K. Schum. }\end{array}$ & $95.39 \pm 8.92^{\mathrm{b}, \mathrm{c}}$ & $138.36 \pm 9.5^{d}$ & ++ & ++ & $\begin{array}{l}\text { Highly potential } \\
\text { candidate }\end{array}$ \\
\hline Alpinia galanga Wild & $125.89 \pm 12.3^{\mathrm{a}}$ & $173.45 \pm 10.9^{b}$ & ++ & ++ & $\begin{array}{l}\text { Highly potential } \\
\text { candidate }\end{array}$ \\
\hline Anethum graveolens $L$. & $92.54 \pm 7.49^{\mathrm{b}, \mathrm{c}}$ & $99.25 \pm 8.9^{\mathrm{e}}$ & + & + & Potential candidate \\
\hline Apium graveolens $L$. & $78.67 \pm 6.95^{\mathrm{d}}$ & $85.95 \pm 6.4^{\mathrm{e}}$ & + & + & Potential candidate \\
\hline $\begin{array}{l}\text { Armoracia rusticana } \\
\text { Gaerth }\end{array}$ & $112.24 \pm 11.4^{\mathrm{b}}$ & $158.15 \pm 12.3^{\mathrm{c}}$ & ++ & ++ & $\begin{array}{l}\text { Highly potential } \\
\text { candidate }\end{array}$ \\
\hline $\begin{array}{l}\text { Artemisia dracunculus } \\
\text { L. }\end{array}$ & $89.35 \pm 6.8^{\mathrm{b}}$ & $99.95 \pm 9.8^{\mathrm{e}}$ & + & + & Potential candidate \\
\hline Capparis spinosa $\mathrm{L}$. & $101.28 \pm 9.65^{\mathrm{b}, \mathrm{c}}$ & $144.26 \pm 11.2^{\mathrm{d}}$ & ++ & ++ & $\begin{array}{l}\text { Highly potential } \\
\text { candidate }\end{array}$ \\
\hline Carum carvi L. & $60.59 \pm 5.64^{\mathrm{e}}$ & $72.58 \pm 5.69^{\mathrm{e}}$ & + & + & Potential candidate \\
\hline Citrus hystrix DC & $75.48 \pm 6.25^{\mathrm{d}}$ & $86.49 \pm 5.98^{\mathrm{e}}$ & + & + & Potential candidate \\
\hline Crocus sativus $L$. & $59.68 \pm 6.58^{\mathrm{e}}$ & $72.89 \pm 5.21^{\mathrm{e}}$ & + & + & Potential candidate \\
\hline $\begin{array}{l}\text { Elettaria cardamomum } \\
\text { (L.) Maton }\end{array}$ & $55.49 \pm 5.98^{\mathrm{e}}$ & $59.56 \pm 4.56^{\mathrm{f}}$ & + & + & Potential candidate \\
\hline Ferula asafetida $L$ & $85.38 \pm 6.27^{\mathrm{c}}$ & $89.44 \pm 6.48^{\mathrm{e}}$ & + & + & Potential candidate \\
\hline $\begin{array}{l}\text { Garcinia indica } \\
\text { Choisy }\end{array}$ & $76.49 \pm 5.87^{\mathrm{d}}$ & $88.35 \pm 4.59^{\mathrm{e}}$ & + & + & Potential candidate \\
\hline Hyssopus officinalis L. & $38.66 \pm 4.23^{\mathrm{f}}$ & $45.08 \pm 3.56^{\mathrm{f}}$ & + & + & Potential candidate \\
\hline
\end{tabular}

Results are Means \pm SD. Values not sharing a common superscript (a-f) differ significantly at $\mathrm{p}<0.05$, Duncan's Multiple Range Test (DMRT). The quantity of flavonoid is expressed as $\mathrm{mg}$ of rutin-equiv/ gm of dry mass and the quantity of polyphenol is expressed as $\mathrm{mg}$ of gallic acid-equiv/gm of dry mass. ++: exceptionally maximum activity or bulk quantities of polyphenols; +significant activity or significant quality of polyphenol.

The symbolization "double plus" is employed to signify an exceptionally high effect or bulky masses of total polyphenols in the spices. The note "single plus" is aimed to denote a noteworthy activity or a notable mass of polyphenols. Table 5 shows that the methanolic extracts of spices, 
specifically A. calamus, A. galanga, A. rusticana, $C$. spinosa, and A. melegueta showed exceedingly significant effects and also comprise large amounts of total flavonoids and polyphenols.

\section{DISCUSSION}

Over the last decade, spices and medicinal herbs have been valued and recognized as medicinal sources worldwide and have a greater influence on both international health and trade. Therefore, spices and therapeutic herbs continue to play a significant function in the pharmaceutical and healthcare system of the global population [37, 38]. The conventional system of medicine is broadly used as Complementary and Alternative Medicine (CAM) in India, China, Korea, Africa, Europe, Iran, and other parts of the world, which has a substantial quantity of investigation on medicinal chemistry, pharmacognosy, pharmacology, and clinical therapeutics. CAM is the term for medical products and practices that are used along with standard medical treatments practiced by several health professionals [39]. The herbal products have been consumed as "dietary supplements" that have been with various vitamins, and minerals, intended to complement the diet, which potentially provide a positive effect on health beyond basic nutrition as functional foods [40]. Indeed, there are several spices and medicinal herbs being consumed for the inhibition and therapeutic effect on inflammation and cancer [41]. Nevertheless, merely a limited number of herbs have attracted the attention of researchers to explore the medication for tumor or cancer (neoplasm).

Various complications of the currently used anti-inflammatory and antineoplastic drugs have ensued in either withdrawal or reduction of these medications from the pharmacological market. It is fascinating to explore that certain spices and medicinal herbs preferentially inhibited the generation of TNF- $\alpha$ and NO, which is believed to be accountable for modulating inflammation besides their crucial role in immune-inflammatory response [42]. These inflammatory substances are also recognized to cause cell death and tissue injury since NO can respond with free radicals (superoxides) to yield peroxynitrite that can lead to permanent damage to cell membranes [6, 13]. Production of these NO causing membrane injury ultimately leads to cancer formation [41]. This outcome specifies the implication of certain spices and medicinal herbs as possible candidates for effective and safe anti-inflammatory/anticancer agents. Chronic inflammation plays a greater role in the burdens related to pathological conditions in both advanced and emerging nations. Studies have also exposed that phenolics and flavonoids act as exceptional anti-inflammatory agents [35].

The anti-inflammatory properties of flavonoids have been widely studied and favorable effects have been demonstrated in many animal models [36, 43]. Inhibition of NO is not considered a general feature of plant flavonoids and phenolic compounds. However, these compounds have been reported to inhibit NO production, thereby downregulating the expression of NO [36]. In this study, A. calamus, A. galanga, A. rusticana, C. spinosa, and A. melegueta exhibited significant concentration-dependent inhibitory effects counter to the generation of NO and TNF- $\alpha$ with lower $\mathrm{CC}_{50}$ values.

All spice extracts presented significant cell viabilities (higher in Acorus calamus L. - 108.95\% and lower in Elettaria cardamomum (L.) Maton - 48.68\%). These outcomes suggest that the methanolic extracts of spices express low toxicity and these results coincide with the previous studies that display the least toxicity effects [33, 34, 36, 41, 43]. The results of excess production of NO may lead to the initiation and progression of cancer formation [44-46]. In this circumstance, 
agents that inhibit the generation of NO are valuable. In our study, all spices exhibited the maximum inhibitory effect against the generation of NO and these outcomes strongly acclaim that the spice extracts possess anti-inflammatory substances. Previous studies reveal that polyphenols are a major class of anti-inflammatory constituents [11, 27-29]. The correlation between the greater anti-inflammatory effects and total flavonoid and phenolic contents of the spices are shown in Table 5. The presentable results are consistent with the earlier reports that the quantities of total flavonoid and phenolic compounds show anti-inflammatory activities [6, 47, 48]. In respect to total flavonoid and polyphenols, phenolic acids (acetosyringone, 4-hydroxybenzoic acid, syringaldehyde, cinnamic acid, caffeic acid, ferulic acid, and tannic acid) were isolated from Acorus calamus [49], kaempferol and quercetin from Armoracia rusticana [50], quercetin encompass the huge amount in Capparis spinosa [51], 1'-acetoxychavicol acetate in Alpinia galangal [52], and eugenol in Aframomum melegueta [53]. Therefore, it is resolved that the chemical constituents of these polyphenol/flavonoids may be responsible for the antiinflammatory properties.

Continued oxidative stress can lead to inflammation and tissue injury that may be a possible root cause of tumor development and progression [54]. Hence, the representatives/substances that concurrently have antioxidant, anti-inflammatory and antineoplastic ingredients are beneficial for the inhibition and management of cancer [1, 4]. Fifteen spices examined in the present investigation showed biochemical activities and thus all listed spices are highly appropriate candidates for anticancer medications. Flavonoids in particular and polyphenols, in general, are recognized in the previous investigations to be extremely possible anti-tumorigenic agents [3, 28, 29, 54-56]. All spices inspected in this investigation indicated a noteworthy correlation of anticancer activities with their total flavonoid and phenolic quantities. A. calamus, A. galanga, A. rusticana, $C$. spinosa, and $A$. melegueta exhibited maximum to medium quantities of flavonoids and polyphenols and demonstrated noteworthy anticancer effects.

For instance, phenolic compounds such as gallic acid and protocatechuic acids that are normally present in nature have attained more consideration due to their superior pharmacological properties $[57,58]$. Both phenolics have been proved to exhibit dose-dependent cytotoxicity on prostate (PC-3) and breast (MCF-7) cancer cells [59]. Mechanistically, gallic acid inhibited the histone deacetylase enzyme thus modifying the acetylation process thereby inducing the cancer cell death [60]. Protocatechuic acid targets the RhoB activation leading to decreased MMP-2 production thus inhibiting cancer cell migration [58]. These compounds induce apoptosis and enhance lactate dehydrogenase levels by reducing the mitochondrial membrane potential. In addition, these compounds trigger the fragmentation of DNA in breast, lung, liver, and prostate cancer cell lines [61]. Similarly, gallic acid inhibits cancer cell proliferation by promoting the generation of reactive oxygen species and arresting cells in the G2/M phase [62]. Similarly, another phenolic compound, caffeic acid, which is also a well-known antioxidant, reported modulating key signaling pathways such as NF- k $\beta$, MAPK and AKT [63]. Furthermore, caffeic acid induced cell death via apoptosis and cell cycle arrest in cell lines representing carcinomas of the oral cavity, neck, and tongue [64].

Thus, it can be concluded that the antineoplastic activity exerted by these spice extracts could be due to the presence of phenolic acids. However, the utility of crude extracts comprising a mixture of phenolic compounds as medicines requires comprehensive studies as the quantity of each phenolic compound in the extract might differ from source to source as well as from the method of extraction and fractionation. 


\section{CONCLUSION}

In the present study, a novel correlation of the immunomodulatory and antineoplastic effects with the polyphenol contents of 15 spices was presented. A. calamus, A. galanga, A. rusticana, $C$. spinosa, and $A$. melegueta are acknowledged in this investigation as significant candidates for the sighting of novel antineoplastic agents. This immunomodulatory and antineoplastic effect of the spices is due to the presence of phenolic and flavonoid composition which hass a relatively high antioxidant potential as well as the ability to combat oxidative stress associated with cancer. It is, therefore, concluded that these five spices are an extremely potent source of bioactive compounds for the discovery of novel antineoplastic agents, suggesting its use in medicine and food industries.

List of Abbreviations: AKT- serine/threonine-specific protein kinase, $\mathrm{AlCl}_{3}$ - aluminium chloride, ANOVA- analysis of variance, ATCC- American type culture collection, CAMcomplementary and alternative medicine, $\mathrm{CC}_{50}$ - cytotoxic concentration, DMEM- Dulbecco's Modified Eagle Medium, DMSO- dimethyl sulfoxide, DNA- deoxyribonucleic acid, ELISAenzyme linked immunosorbent assay, FBS- fetal bovine serum, $\mathrm{H}_{3} \mathrm{PO}_{4}$ - phosphoric acid, LPSlipopolysaccharides, MAPK- mitogen-activated protein kinase, MMP-2- Matrix metalloproteinase-2, MTT- 3-(4, 5-dimethylthiazolyl-2)-2, 5-diphenyltetrazolium bromide), NF$\mathrm{k} \beta$ - nuclear factor kappa B, NO- nitric oxide, OD- optical density, SPSS- statistical package for the social sciences, TNF- $\alpha$-tumor necrosis factor-alpha.

Acknowledgments: The authors sincerely acknowledge the Dean, faculty members and technical staff in the Faculty of Medicine, Management and Science University, Malaysia who provided a great deal of support, technical assistance and cooperation in the study.

Competing Interest: The authors declare that they have no conflict of interest.

Author's Contributions: All authors contributed to this study

Human and Animal Studies: This article does not contain any studies with human or animal subjects.

\section{REFERENCES}

1. Ganesan K, Sukalingam K, Xu B: Impact of consumption of repeatedly heated cooking oils on the incidence of various cancers- A critical review. Crit Rev Food Sci Nutr 2019, 59:488-505.

2. Ganesan K, Guo S, Fayyaz S, Zhang G, Xu B: Targeting Programmed Fusobacterium nucleatum Fap2 for Colorectal Cancer Therapy. Cancers 2019, 11:1592.

3. Ganesan K, Xu B: Molecular targets of vitexin and isovitexin in cancer therapy: a critical review. Ann NY Acad Sci 2017, 1401:102-113.

4. Ganesan K, Xu B: Telomerase Inhibitors from Natural Products and Their Anticancer Potential. Int J Mol Sci 2017, 19:pii E13.

5. Siegel RL, Miller KD, Jemal A: Cancer statistics, 2020. CA Cancer J Clin 2020, 70: 7-30.

6. Jayachandran M, Wu Z, Ganesan K, Khalid S, Chung SM, Xu B: Isoquercetin upregulates antioxidant genes, suppresses inflammatory cytokines and regulates AMPK pathway in streptozotocin-induced diabetic rats. Chem Biol Interact 2019, 303: 62-69. 
7. Ganesan K, Sukalingam K, Xu B: Impact of consumption and cooking manners of vegetable oils on cardiovascular diseases- A critical review. Trends Food Sci Technol 2018, 71:132-154.

8. Sukalingam K, Ganesan K, Xu B: Protective effect of aqueous extract from the leaves of Justicia tranquebariesis against thioacetamide-induced oxidative stress and hepatic fibrosis in rats. Antioxidants 2018, 7:78.

9. Zhang T, Jayachandran M, Ganesan $\mathrm{K}, \mathrm{Xu}$ B. Black truffle aqueous extract attenuates oxidative stress and inflammation in STZ-induced hyperglycemic rats via Nrf2 and NF$\kappa \mathrm{B}$ pathways. Front Pharmacol 2018, 9.

10. Ganesan K, Xu B: Anti-diabetic effects and mechanisms of dietary polysaccharides. Molecules 2019, 24: E2556.

11. Islam T, Ganesan K, Xu B: New insight into mycochemical profiles and antioxidant potential of edible and medicinal mushrooms: A review. Int J Med Mushrooms 2019, 21:237-251.

12. Nair SKP, Ganesan K, Azalewor HG, Letha N, Gani SB: Preliminary phytochemical screening and in vitro antioxidant activity of ethiopian indigenous medicinal plants, Ocimum lamiifolium Hochst. ex Benth and Ocimum basilicum L. Int J Pharma Sci Drug Res 2016, 8:30-36.

13. Kumar G, Banu GS, Murugesan AG: Effect of Helicteres isora bark extracts on heart antioxidant status and lipid peroxidation in streptozotocin diabetic rats. J Appl Biomed 2008, 6:89-95.

14. Liu Q, Meng X, Li Y, Zhao CN, Tang GY, Li HB: Antibacterial and Antifungal Activities of Spices. Int J Mol Sci 2017, 18:1283.

15. Ali NH, Faizi S, Kazmi SU: Antibacterial activity in spices and local medicinal plants against clinical isolates of Karachi, Pakistan. Pharma Biol. 2011, 49:833-839.

16. Mickymaray S, Al Aboody MS: In vitro antioxidant and bactericidal efficacy of 15 common spices: Novel therapeutics for urinary tract infections? Medicina 2019, 55: 289.

17. Rath S, Padhy RN: Monitoring in vitro antibacterial efficacy of 26 Indian spices against multidrug resistant urinary tract infecting bacteria. Integ Med Res 2014, 3:133-141.

18. Mickymaray, S., Al Aboody MS, Rath PK, Annamalai P, Nooruddin T: Screening and antibacterial efficacy of selected Indian medicinal plants. Asian Pac J Trop Biomed 2016, 6:185-191.

19. Mickymaray S, Alturaiki W: Antifungal efficacy of marine macroalgae against fungal isolates from bronchial asthmatic cases. Molecules 2018, 23:3032.

20. Sharifi-Rad J, Sureda A, Tenore GC, Daglia M, Sharifi-Rad M, Valussi M, Tundis R, Sharifi-Rad M, Loizzo MR, Ademiluyi AO, Sharifi-Rad R, Ayatollahi SA, Iriti M. Biological activities of essential oils: From plant chemoecology to traditional healing systems. Molecules 2017, 22:70.

21. Subbu lakshmi S, Chelladurai G, Suresh B: In vitro studies on medicinal plants used against bacterial diabetic foot ulcer (BDFU) and urinary tract infected (UTI) causing pathogens. J Parasit Dis 2014, 40:667-673.

22. Vinodhini R, Moorthy K, Suresh M: Incidence and virulence traits of Candida dubliniensis isolated from clinically suspected patients. Asian J Pharma Clin Res 2016, 9:77. 
23. Arena A, Bisignano G, Pavone B, Tomaino A, Bonina FP, Saija A, Cristani M, D'Arrigo M, Trombetta D: Antiviral and immunomodulatory effect of a lyophilized extract ofCapparis spinosa L. buds. Phytother Res 2008, 22:313-317.

24. Belska NV, Guriev AM, Danilets MG, Trophimova ES, Uchasova EG, Ligatcheva AA, Belousov MV, Agaphonov VI, Golovchenko VG, Yusubov MS, Belsky YP: Watersoluble polysaccharide obtained from Acorus calamus L. classically activates macrophages and stimulates Th1 response. Int Immunopharmacol 2010, 10:933-942.

25. Vellayutham R, Patil VS: In vitro evaluation for immunomodulatory activity of Acorus calamus on human neutrophils. Int Res J Pharmacy 2015, 6:450-452.

26. Pal Jain A, Pawar RS, Lodhi S, Singhail AK: Immunomodulatory and anti-oxidant potential of Alpinia galanga Linn. rhizomes. Pharmacogn Comm 2012, 2:30-37.

27. Ganesan K, Chung SK, Vanamala J, Xu B: Causal relationship between diet-induced gut microbiota changes and diabetes: A novel strategy to transplant Faecalibacterium prausnitzii in preventing diabetes. Int J Mol Sci 2018, 19:3720.

28. Ganesan K, Xu B: Polyphenol-Rich Dry Common Beans (Phaseolus vulgaris L.) and Their Health Benefits. Int J Mol Sci 2017, 18:2331.

29. Ganesan K, Xu B: Polyphenol-Rich Lentils and Their Health Promoting Effects. Int J Mol Sci 2017, 18:2390.

30. Mitić VD, Stankov-Jovanovića VP, Jovanovića OP, Palića IR, Djordjevića AS, Stojanović GS: Composition and antioxidant activity of hydrodistilled essential oil of Serbian Ajuga chamaepitys (L.) Schreber ssp.chia (Schreber) Arcangeli. J Essent Oil Res 2011, 23:7074.

31. Stojanović G, Stojanović I, Jovanović VS, Mitić V, Kostić D: Reducing power and radical scavenging activity of four Parmeliaceae species. Open Life Sci, 2010, 5:808-813.

32. Ni L-J, Wang N-N, Zhang L-G, Guo Y-Z, Shi W-Z: Evaluation of the effects of active fractions of chinese medicine formulas on IL- $1 \beta$, IL- 6 , and TNF- $\alpha$ release from ANA-1 murine macrophages. J Ethnopharmacol 2016, 179:420-431.

33. Zhang L, Koyyalamudi SR, Jeong SC, Reddy N, Bailey T, Longvah T: Immunomodulatory activities of polysaccharides isolated from Taxillus chinensis and Uncaria rhyncophylla. Carbohydr Polym 2013, 98:1458-1465.

34. Zhang L, Koyyalamudi SR, Jeong SC, Reddy N, Smith PT, Ananthan R, Longvah T: Antioxidant and immunomodulatory activities of polysaccharides from the roots of Sanguisorba officinalis. Int J Biol Macromol 2012, 51:1057-1062.

35. Zhang L, Ravipati AS, Koyyalamudi SR, Jeong SC, Reddy N, Smith PT, Bartlett J, Shanmugam K, Münch G, Wu MJ: Antioxidant and Anti-inflammatory Activities of Selected Medicinal Plants Containing Phenolic and Flavonoid Compounds. J Agri Food Chem 2011, 59:12361-12367.

36. Ravipati AS, Zhang L, Koyyalamudi SR, Jeong SC, Reddy N, Bartlett J, Smith PT, Shanmugam K, Münch G, Wu MJ, Satyanarayanan M, Vysetti B: Antioxidant and antiinflammatory activities of selected Chinese medicinal plants and their relation with antioxidant content. BMC Complement Altern Med 2012, 12:173

37. Ganesan K, Xu B: Anti-Obesity Effects of Medicinal and Edible Mushrooms. Molecules 2018, 23:2880. 
38. Sukalingam K, Ganesan K, Xu B: Trianthema portulacastrum L. (giant pigweed): phytochemistry and pharmacological properties. Phytochem Rev 2017, 16:461-478.

39. Ganesan K, Xu B: Ethnobotanical studies on folkloric medicinal plants in Nainamalai, Namakkal District, Tamil Nadu, India. Trends Phytochem Res 2017, 1:153-168.

40. Sukalingam K, Ganesan K, Ponnusamy K: Evaluation of antidiabetic activity of polyherbal formulations on type 2 diabetic patients: A single blinded randomized study. Int J Integ Medl Sci 2015, 2:90-98

41. Husain I, Ahmad R, Chandra A, Raza ST, Shukla Y, Mahdi F: Phytochemical characterization and biological activity evaluation of ethanolic extract of Cinnamomum zeylanicum. J Ethnopharmacol. 2018, 219:110-116.

42. Kumar P, Febriyanti R, Sofyan F, Luftimas D, Abdulah R: Anticancer potential of Syzygium aromaticum L. in MCF-7 human breast cancer cell lines. Pharmacogn Res 2014, 6: 350 .

43. Talhouk RS, Karam C, Fostok S, El-Jouni W, Barbour EK: Anti-Inflammatory Bioactivities in Plant Extracts. J Med Food 2007, 10:1-10.

44. Blaser H, Dostert C, Mak TW, Brenner D. TNF and ROS Crosstalk in Inflammation. Trends Cell Biol 2016, 26:249-261.

45. Hecht F, Pessoa CF, Gentile LB, Rosenthal D, Carvalho DP, Fortunato RS: The role of oxidative stress on breast cancer development and therapy. Tumor Biol. 2016, 37:42814291.

46. Pisoschi AM, Pop, A: The role of antioxidants in the chemistry of oxidative stress: A review. Eur J Med Chem 2015, 97:55-74.

47. Anhê FF, Roy D, Pilon G, Dudonné S, Matamoros S, Varin TV, Garofalo C, Moine Q, Desjardins Y, Levy E, Marette A. A polyphenol-rich cranberry extract protects from dietinduced obesity, insulin resistance and intestinal inflammation in association with increasedAkkermansiaspp. population in the gut microbiota of mice. Gut 2014, 64: 872883.

48. Le Sage F, Meilhac O, Gonthier MP: Anti-inflammatory and antioxidant effects of polyphenols extracted from Antirhea borbonica medicinal plant on adipocytes exposed to Porphyromonas gingivalis and Escherichia coli lipopolysaccharides. Pharmacol Res 2017, 119:303-312.

49. Singh S, Srivastava R, Choudhary S: Antifungal and high-performance liquid chromatography analysis of the crude extracts of Acorus calamus, Tinospora cordifolia and Celestrus paniculatus. Arch Phytopathol Plant Protect 2011, 44: 902-910.

50. Gafrikova M, Galova E, Sevcovicova A, Imreova P, Mucaji P, Miadokova E: Extract from Armoracia rusticana and its flavonoid components protect human lymphocytes against oxidative damage induced by hydrogen peroxide. Molecules 2014, 19: 3160-3172.

51. Kalantari H, Foruozandeh H, Khodayar MJ, Siahpoosh A, Saki N, Kheradmand P: Antioxidant and hepatoprotective effects of Capparis spinosa L. fractions and Quercetin on tert-butyl hydroperoxide- induced acute liver damage in mice. J Tradit Complement Med 2018, 8:120-127.

52. Tang X, Xu C, Yagiz Y, Simonne A, Marshall MR: Phytochemical profiles, and antimicrobial and antioxidant activities of greater galangal [Alpinia galanga (Linn.) Swartz.] flowers. Food Chemistry 2018, 255:300-308. 
53. Mohammed A, Koorbanally NA, Islam MS: Phytochemistry, antioxidative activity and inhibition of key enzymes linked to type 2 diabetes by various parts of Aframomum melegueta in vitro. Acta Pol Pharm 2016, 73:403-17.

54. Ponnusamy K, Shaker IA, Ganesan K, Ishaka A, Changmai MC, Ariffin IA. L-Carnitine (Vitamin BT) - A Potent Immunomodulatory, Xenobiotics-Detoxifying, Anti-Mutagenic Nutrigenomic Molecular Medicine. J Mgt Sci 2013, 11:1-14.

55. Ganesan K, Xu B: A critical review on phytochemical profile and health promoting effects of mung bean (Vigna radiata). Food Sci Human Wellness 2018, 7:11-33.

56. Ganesan K, Xu B: A Critical Review on Polyphenols and Health Benefits of Black Soybeans. Nutrients 2017, 9: pii: E455.

57. Ho, HH, Chang CS, Ho WC, Liao SY, Lin WL, Wang CJ: Gallic acid inhibits gastric cancer cells metastasis and invasive growth via increased expression of RhoB, downregulation of AKT/small GTPase signals and inhibition of NF- $\mathrm{kB}$ activity. Toxicol Appl Pharmacol 2013, 266:76-85.

58. Lin HH, Chen JH, Chou FP, Wang CJ: Protocatechuic acid inhibits cancer cell metastasis involving the down-regulation of Ras/Akt/NF- $\mathrm{KB}$ pathway and MMP-2 production by targeting RhoB activation. Br J Pharmacol. 2010, 162:237-254.

59. Kassi E, Chinou I, Spilioti E, Tsiapara A, Graikou K, Karabournioti S, Manoussakis M, Moutsatsou P: A monoterpene, unique component of thyme honeys, induces apoptosis in prostate cancer cells via inhibition of NF-kB activity and IL-6 secretion. Phytomed 2014, 21:1483-1489.

60. Seidel C, Schnekenburger M, Dicato M, Diederich M: Antiproliferative and proapoptotic activities of 4-hydroxybenzoic acid-based inhibitors of histone deacetylases. Cancer Lett 2014, 343:134-146.

61. Yin MC, Lin CC, Wu HC, Tsao SM, Hsu CK: Apoptotic Effects of Protocatechuic Acid in Human Breast, Lung, Liver, Cervix, and Prostate Cancer Cells: Potential Mechanisms of Action. J Agri Food Chem 2009, 57:6468-6473.

62. Chen HM, Wu YC, Chia YC, Chang FR, Hsu HK, Hsieh YC, Chen CC, Yuan SS: Gallic acid, a major component of Toona sinensis leaf extracts, contains a ROS-mediated anticancer activity in human prostate cancer cells. Cancer Lett. 2009, 286:161-171.

63. Wang LC, Chu KH, Liang YC, Lin YL, Chiang BL:Caffeic acid phenethyl ester inhibits nuclear factor- $\mathrm{kB}$ and protein kinase $\mathrm{B}$ signalling pathways and induces caspase-3 expression in primary human CD4+ T cells. Clin Exp Immunol. 2010, 160:223-232.

64. Fukuda M, Kobayashi K, Hirono Y, Miyagawa M, Ishida T, Ejiogu EC, Sawai M, Pinkerton KE, Takeuchi M: Jungle Honey Enhances Immune Function and Antitumor Activity. Evid Based Complement Alternat Med 2011, 2011:908743. 